\title{
Career Choice Motives of Secondary School Students in Latvia
}

\author{
Rita Burceva, Rezekne, Ruta Geidane, Rezekne \\ Academy of Technologies, Latvia
}

\begin{abstract}
.
The topicality of this article is related to studying the motives for choosing a profession as a mechanism of personal development and its impact on successful professional activity. The practical significance of this study is the opportunity to use the results in diagnostic and career choice activities with school students and develop methodology for successful integration of school graduates on the job market. The research aim is to study career choice motives of secondary school students. The research object is the career choice of secondary school students. To gather empirical data, a questionnaire was designed for the survey. The respondent sample included 152 students in grade 10, 11, and 12 at Rezekne Secondary School No.5. The research results set us thinking that the majority of school students need the help of a school career counsellor. An important criterion of an individual's professional formation is independent and purposeful building of a career, making responsible decisions regarding the choice of a profession. An important role in making any decision (including the choice of a career) is held by the individual's motivation, the formation of which is guided by different motives. The number of motives, the driving force of each motive, and actualization of situational factors determine the general level of motivation. School career counsellors need to take up a bigger role in forming the students' motivation through communication with the students, their families, the school's support staff, local government and manufacturing enterprises.
\end{abstract}

Keywords: career decision, motives, school career counsellor, secondary school

\section{Introduction}

In the latest decades, with the changing situation on the job market, not only new professions have appeared which require new skills and knowledge, but approaches to career planning and choosing a profession have also changed. This is why students need to be given an opportunity to understand the rapid development trends of the national economy and the job market, evaluate the role of various factors and circumstances in planning and building a personal career. An informed choice of a profession affects one's entire life, determines selfrealization, socialization, and career growth success. It is important to help school students to acquire and develop the ability to link their interests, abilities and opportunities, which can be actualized in the achievement of career goals even in the uncertain circumstances which we have been facing lately in relation to the transformation of people's habits and epidemiological challenges. These challenges set us thinking about innovative approaches to 


\section{5th International Conference on New Findings On HUMANITIES AND SOCIAL SCIENCES}

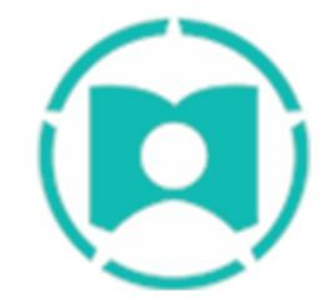

\section{0-22 NOVEMBER, 2020 PARIS, FRANCE}

career development support for school students, as well as the ability of school career counsellors to adapt and acquire new work forms - distance counselling, adaptation of foreign methods and work approaches in the Latvian educational environment.

The topicality of this article is related to studying the motives for choosing a profession as a mechanism of personal development and its impact on successful professional activity. The practical significance of this study is the opportunity to use the results in diagnostic and career choice activities with school students and develop methodology for successful integration of school graduates on the job market.

Career choice has always been an important issue. The foundation is laid in the family; whereas the secondary school period is the time when youth especially think about their future. Choosing a profession has been important to everyone at all times; however, in the changing socioeconomic circumstances, decision-making is ever more influenced by different external circumstances rather than just the young individual's desire. All psychological theories concerning personal activity emphasize needs as the primary source of such activity. A. Vorobjovs emphasizes that "the process which is the external content of a need is called a motive (lat. movere- to move, to push). Thus, a motive is an activity directed at a subject, maintained by internal mental condition (necessity), which is "narrowed down" by objective characteristics of the subject of the need. Thus, if the need is characterized by readiness to act, then the presence of a motive imparts on such activity a more focused and effective character". (Vorobjovs, 2002)

The research aim is to study career choice motives of secondary school students. The research object is the career choice of secondary school students. The research subject is career choice motives.

\section{Methods}

To learn about the students' motives for professional choice, in accordance with the research aim, a quantitative empirical research method was used in this study - a survey. To gather empirical data, a questionnaire was designed for the survey. The respondent sample included 152 students in grade 10, 11, and 12 at Rezekne Secondary School No.5.

When preparing the questionnaire questions, the differences in the education and competence levels of the students had to be taken into account, which is why the questions had simple and clear structure to avoid confusing the respondents. Special attention was given to the content of the questions when preparing the questionnaire. The questions were designed to explore the students' plans for the future, their opinions, motives and judgements; whereas the demographic questions helped gather data about the respondents' status. The majority of the questions were closed-ended, and only some questions were open-ended, allowing the respondents to express their beliefs and judgements.

It was important to include questions about the type and amount of information required for choosing a future profession and education, whether this information is available, whether help is needed choosing a profession. The final part of the questionnaire included a question 


\section{5th International Conference on New Findings On HUMANITIES AND SOCIAL SCIENCES}

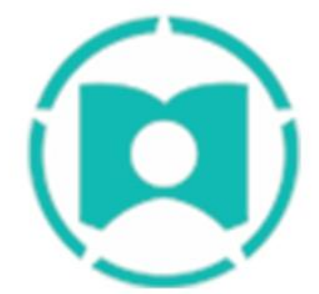

\section{0-22 NOVEMBER, 2020 \\ PARIS, FRANCE}

about the most prestigious professions among youths. Microsoft Excel XP software was used for processing the data of the research questionnaires and the preparation of tables and reports.

\section{Results}

The distribution of respondents by gender and age is summarized in Table 1 .

Table 1. Distribution of Respondents by Age and Gender

\begin{tabular}{|l|c|c|c|}
\hline \multicolumn{1}{|c|}{ Grade } & Number of students & Boys & Girls \\
\hline Grade 10 & 52 & 22 & 30 \\
\hline Grade 11 & 49 & 25 & 24 \\
\hline Grade 12 & 51 & 21 & 30 \\
\hline Total & 152 & 68 & 84 \\
\hline
\end{tabular}

A comparison of the stability of motives in grade ten, eleven, and twelve of secondary school has discovered differences.

Table 2 contains a comparison of motives by importance (how important a particular motive is to $\mathrm{n} \%$ of students of the total number of respondents in the sample).

Table 2. Comparison of Career Choice Motives

\begin{tabular}{|l|c|c|c|}
\hline \multicolumn{1}{|c|}{ Career choice motive } & $\begin{array}{c}\text { Grade 10 } \\
\text { (\% of the } \\
\text { number of } \\
\text { students in } \\
\text { class) }\end{array}$ & $\begin{array}{c}\text { Grade 11 } \\
\text { (\% of the } \\
\text { number of } \\
\text { students } \\
\text { in class) }\end{array}$ & $\begin{array}{c}\text { Grade 12 } \\
\text { (\% of the } \\
\text { number of } \\
\text { students } \\
\text { in class) }\end{array}$ \\
\hline $\begin{array}{l}\text { Correspondence to abilities, interests, } \\
\text { aptitude }\end{array}$ & 86 & 82 & 86 \\
\hline Career growth opportunities & 52 & 71 & 78 \\
\hline Good salary & 63 & 82 & 70 \\
\hline Opportunity to work in a team & 50 & 65 & 68 \\
\hline Prospects of the profession & 52 & 65 & 66 \\
\hline Opportunity for creative expression & 44 & 41 & 59 \\
\hline Prestige of the profession & 58 & 57 & 57 \\
\hline Opportunity for calm work & 38 & 59 & 45 \\
\hline Opportunity to take responsibility & 31 & 41 & 43 \\
\hline Opportunity to work for the good of society & 27 & 28 & 41 \\
\hline Recommendations of parents & 15 & 47 & 31 \\
\hline Experience of acquaintances & 27 & 24 & 27 \\
\hline $\begin{array}{l}\text { Recommendations of school career } \\
\text { counsellor or form tutor }\end{array}$ & 15 & 33 & 23 \\
\hline Opportunity to work abroad & 23 & 37 & 23 \\
\hline Real experience in a particular profession & 7 & 12 & 12 \\
\hline
\end{tabular}




\section{5th International Conference on New Findings On HUMANITIES AND SOCIAL SCIENCES}

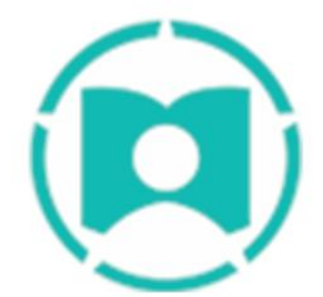

\section{0-22 NOVEMBER, 2020 \\ PARIS, FRANCE}

When comparing the stability of the profession choice motives, it should be emphasized that in all groups of classes the motive named as the most important is the correspondence of the chosen profession to one's abilities, interests, and aptitude; an opportunity to earn good salary is also important (grades 10 and 11); whereas grades 11 and 12 also name the opportunity for career growth as an important motive. The motive of prestige is more important in grade 10; whereas in grades 11 and 12 the opportunity to work in a team and the prospects of the profession are more important. 12-graders highlight the desire for creative expression; whereas in grade 10, the desire to take responsibility shows less than in both other groups of respondents. When choosing a future profession, more 12-graders express the desire to work for the good of society; whereas the recommendations of parents, form tutor and school career counsellor are generally more important to students in grades 11 and 12. The study shows that the majority of the students do not sufficiently appreciate the possible input and help of a school career counsellor exploring the students' career opportunities and making important decisions.

A correlation between the students' age and the importance of the motives of choice was established in the course of the research.

The equation for calculating the correlation:

$$
\operatorname{Correl}(X, Y)=\frac{\sum(x-\bar{x})(y-\bar{y})}{\sqrt{\sum(x-\bar{x})^{2} \sum(y-\bar{y})^{2}}}
$$

where $\mathrm{x}$ and $\mathrm{y}$ are dataset values;

$\bar{x}$ and $\bar{y}-$ mean values of the datasets.

The following correlations were obtained in the study:

- Correlation coefficient between grade 10 and grade 11 data

- Correlation coefficient between grade 11 and grade 12 data

- Correlation coefficient between grade 10 and grade 12 data

It can be concluded that in all three cases the functional correlation between the data is strong, and thus correlation is present in the data.

\section{Discussion}

The sphere of motivation is rather dynamic: the importance and influence of particular motives changes (and the hierarchy of motives also changes). However, it can be stated that motives that encourage action are more stable in the long-term. Thus, the general level of motivation depends on the following:

- the number of motives that encourage action,

- actualization of situational factors,

- $\quad$ the driving force of each particular motive. 


\section{5th International Conference on New Findings On HUMANITIES AND SOCIAL SCIENCES}

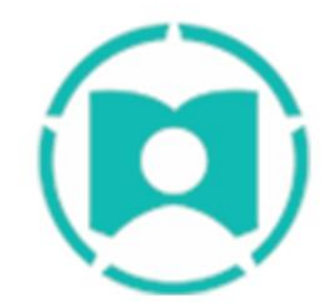

\section{0-22 NOVEMBER, 2020 \\ PARIS, FRANCE}

Not only awareness of the motive is important but also the attitude to it because awareness does not always also mean acceptance. Acceptance happens when the motive contains meaning and is related to the person's beliefs. A person's actions depend on the motive; whereas the motive depends on the internal activity of the person. (Vorobjovs, 2002)

Whereas R.Gibson, M.Mitchell (2006) point out several personal development objectives at the age of youth: the need to prove current professional choice, starting work in the chosen field, exploring new opportunities. The young person's developmental objectives are related to the individual's motivation and are important in the context of this study. The choice of school subjects in secondary school, according to Marcus (2017), is also determined by the youth's thoughts about their future profession. At the same time, Oomen\&Plant (2014) point out the necessity to improve career support in schools to enable youth to acquire career management skills at the level required for making serious career decisions throughout their life. In the context of new career theories, the focus is on the individual's ability to navigate rapidly changing circumstances and to make motivated and self-directed decisions at different stages of their lives (Mitin et al., 2018; Daugol \& Sherstha, 2019).

The survey of the students showed several significant differences by groups of classes. Thus, at the start of grade 10 in secondary school, some students were already more motivated and knew what they wanted when they finish school. Of course, as time goes by, plans change and so do young people - their view of life, attitude to important things, and priorities change; however, stronger motivation is still noticeable. This is also supported by the fact that 12graders are more self-confident and have chosen a profession well in advance, as well as the fact that in a crisis young people generally believe that their choice is correct. However, it is clear that the stereotypes which professions are considered prestigious in society are determined by the attitude of the public, which young people succumb to. These are the professions discussed more in the media in the context of high salary, prestige, and high level of education.

Overall, young people tend to leave the choice of a profession until last while the choice is still possible. However, in the first semester of grade 12, students already have to choose which exams to take at the end of secondary school, and this definitely urges them to consider their professional plans. This also determines their further higher education prospects in specific education programmes, which is why young people are forced to think about their education opportunities after secondary school way in advance.

Current trends in the development of society and the changes on the job market also encourage the acquisition of competitive and quality education. However, unfortunately, in the circumstances of rapid changes and uncertainty, not enough information is available on the job market development trends even for a period of 5-7 years. This makes young people concerned whether current education, which often requires a big financial investment, will be useful in the future and whether their profession will be in demand.

However, the conclusion obtained as a result of the study that high salary in the future profession is a very important factor for youth is also a reflection of the processes that are going on in society. Young people want a secure future, stability, social and economic well- 


\section{5th International Conference on New Findings On HUMANITIES AND SOCIAL SCIENCES}

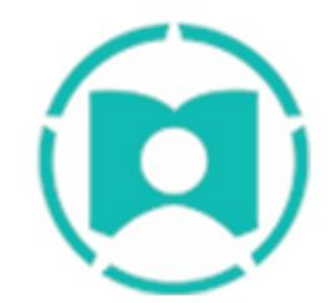

\section{0-22 NOVEMBER, 2020 \\ PARIS, FRANCE}

being, and independence; except that oftentimes the popularity of a profession is illusionary and does not correspond to the real situation, or the profession is even completely unsuitable to the young person.

The research results set us thinking that the majority of school students need the help of a school career counsellor, who is a highly qualified specialist. Even if the students know where to search for information, they often find it difficult to navigate. They also need the opportunity to receive individual consultations, not only to explore themselves and their abilities, but also to gather information about their resources and needs.

This is why one of the ways to help is to provide youth with complete information on education and career planning. However, it would be best not to leave the acquisition of such information unattended hoping that young people will be so conscientious and do everything by themselves. To do that, they often not only lack the skills and knowledge, but also time. Yet, this can be successfully achieved under the guidance of a specialist (school career counsellor), e.g. by integrating career education into the form teacher's sessions or into individual work with students. There is no denying that form teachers in Latvia already try to educate youth on these topics, but still they often lack specific knowledge to do it well.

The majority of the respondents plan to obtain higher education after finishing secondary school, which means that young people understand the real situation on the job market and are aware that specialists with higher education have better chances when competing on the job market.

The decisive factor in the choice of a profession among youth is correspondence to their abilities, interests and aptitude. However, other motives have also been selected as important, especially high salary. This can be explained in two ways: on the one hand, young people are affected by current socioeconomic instability; on the other hand, they want to secure a stable future for themselves and their family.

The second most important motive for choosing a profession found in the future plans of the 12-graders was career growth opportunities. The opinions of young people about the necessity of professional help when choosing further education and a profession differ because some of them want to receive it, and others do not. The importance of career planning and development issues has been actualized in Latvia, and intensive work is currently continued on the design and introduction of a career development support system at different levels; namely, not only general education school teachers are being educated on the issues of career education, but professional career counsellors are being trained in several higher education institutions.

Young people listen to different experiences and advice and try to formulate their own opinion, and the majority are looking for advisers in their immediate circle. Such an adviser could be a school career counsellor.

Thus, the main objectives of career education in order to help school students to understand their needs and explore their problems are the following:

- help to explore their interests and abilities,

- explore the opportunities for developing their abilities, 


\section{5th International Conference on New Findings On HUMANITIES AND SOCIAL SCIENCES}

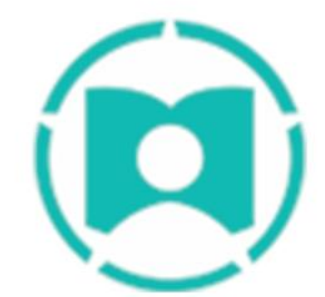

\section{0-22 NOVEMBER, 2020 \\ PARIS, FRANCE}

- gain an idea about further education opportunities in the city/town, country, or abroad that are related to their interests,

- $\quad$ help to plan their education in relation to their interests,

- motivate students to take responsibility for their education,

- $\quad$ help to find education opportunities available after finishing grade 9 and 12,

- $\quad$ find an individual approach to each student to evaluate their needs, provide support when students make personal career decisions, considering their social, cultural, and economic circumstances.

\section{Conclusions}

An important criterion of an individual's professional formation is independent and purposeful building of a career, making responsible decisions regarding the choice of a profession.

An important role in making any decision (including the choice of a career) is held by the individual's motivation, the formation of which is guided by different motives. The number of motives, the driving force of each motive, and actualization of situational factors determine the general level of motivation. Pedagogical literature has no uniform classification of career choice motives; motives (regardless of their type) are acquired in the course of the person's life and are formed as a result of their individual experience.

The research results call for the search of an optimum way to implement career education in secondary school. When working with school students, it is recommended to implement career education in a successive way, so that students receive information appropriate for their age and interests, acquiring knowledge in a specific aspect of education (information about career, self-evaluation, developing skills, etc.) and form of learning (school subject, form teacher's session, various after-school activities, etc.), as well as general skills related to working experience, which would help to take action in familiar as well as new life situations, using the following plan:

- in grade 10, emphasize self-exploration,

- in grade 11, emphasize learning about the education opportunities and the world of professions,

- in grade 12 , emphasize the aspects of making a decision.

School career counsellors need to take up a bigger role in forming the students' motivation through communication with the students, their families, the school's support staff, local government and manufacturing enterprises.

\section{References}

Daugol, R.,\& Sherstha, M. (2019).Learning Readiness and Educational Achievement among School Students. The International Journal of Indian Psychology, Vol. 7 (2), pp. 467-476.

Gibson, R. L. and Mitchell, M. H. (2006). Introduction to Counseling and Guidance. New Yersey, Upper Saddle River. 


\section{5th International Conference on New Findings On HUMANITIES AND SOCIAL SCIENCES}

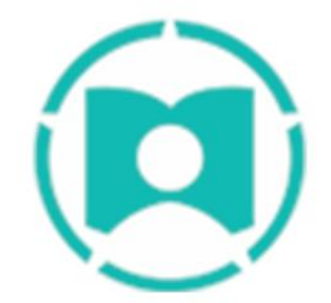

\section{0-22 NOVEMBER, 2020 \\ PARIS, FRANCE}

Marcus, P. (2017). The psychoanalysis of career choice, job performance, and satisfaction. How to flourish in the workplace . London and New York: Routledge.

Mitin, S.N., Kidinov, A.V., Fedotov, S.N., Leontev, M.G., Bolotova, A.K., \& Kalinin, I.V. (2018). Modern Models Of Career Readiness. Modern Journal of Language Teaching Methods, Vol. 8 (3), pp.78-86.

Oomen, A., \& Plant, P. (2014). Early School Leaving and Lifelong Guidance. Jyväskylä: University of Jyväskylä - Finnish Institute for Educational Reserch. Available: http://www.elgpn.eu/publications

Vorobjovs, A. (2002). Sociālā psihologija [Social psychology]. Riga.

For each work shown in the list of references must be a reference in the text. All citations in the text and all references must meet APA styles (American Psychological Association 7th edition - more information http://www.apastyle.org/).

(Book style - Author, year. Title (in italics). Publisher, location of publisher.)

Cichocki, A. and Unbehaven, R., (1993). Neural Networks for Optimization and Signal Processing, 1st ed. Chichester, U.K.: Wiley.

Chen, W. K. (1993). Linear Networks and Systems, Belmont, CA: Wadsworth, pp. 123-135.

(Journal - Author, year. Paper title. Journal name (in italics), volume and issue numbers, inclusive pages.)

Chen, S., Mulgrew, B. and Granta, P. M. (1993). "A clustering technique for digital communications channel equalization using radial basis function networks," IEEE Trans. on Neural Networks, vol. 4, pp. 570-578.

Hill, R. M. (1997). The single-vendor single-buyer integrated production-inventory model with a generalized policy, European Journal of Operational Research, vol. 97, pp. 493-499.

\section{(Online Sources style)}

Vidmar, R. J. (August 1992). On the use of atmospheric plasmas as electromagnetic reflectors. IEEE Trans. Plasma Sci. [Online]. 21(3). pp. 876-880. Available: http://www.halcyon.com/pub/journals/21ps03-vidmar

(Conference paper or contributed volume - Author, year, paper title. Proceedings title (in italics). City, country, inclusive pages.)

Beck, K. and Ralph, J. (1994). Patterns Generates Architectures. Proceedings of European Conference of Object-Oriented Programming. Bologna, Italy, pp. 139-149. 